\title{
Toxigenic and non-toxigenic Clostridium difficile: determinants of intestinal colonisation and role in childhood atopic manifestations
}

Citation for published version (APA):

Penders, J., Stobberingh, E. E., van den Brandt, P. A., Van Ree, R., \& Thijs, C. (2008). Toxigenic and non-toxigenic Clostridium difficile: determinants of intestinal colonisation and role in childhood atopic manifestations. Gut, 57(7), 1025-6. https://doi.org/10.1136/gut.2007.143214

Document status and date:

Published: 01/01/2008

DOI:

10.1136/gut.2007.143214

Document Version:

Publisher's PDF, also known as Version of record

Document license:

Taverne

Please check the document version of this publication:

- A submitted manuscript is the version of the article upon submission and before peer-review. There can be important differences between the submitted version and the official published version of record.

People interested in the research are advised to contact the author for the final version of the publication, or visit the DOI to the publisher's website.

- The final author version and the galley proof are versions of the publication after peer review.

- The final published version features the final layout of the paper including the volume, issue and page numbers.

Link to publication

\footnotetext{
General rights rights.

- You may freely distribute the URL identifying the publication in the public portal. please follow below link for the End User Agreement:

www.umlib.nl/taverne-license

Take down policy

If you believe that this document breaches copyright please contact us at:

repository@maastrichtuniversity.nl

providing details and we will investigate your claim.
}

Copyright and moral rights for the publications made accessible in the public portal are retained by the authors and/or other copyright owners and it is a condition of accessing publications that users recognise and abide by the legal requirements associated with these

- Users may download and print one copy of any publication from the public portal for the purpose of private study or research.

- You may not further distribute the material or use it for any profit-making activity or commercial gain

If the publication is distributed under the terms of Article $25 \mathrm{fa}$ of the Dutch Copyright Act, indicated by the "Taverne" license above, 
and INR. MELD scores can range from 6 to 40 (MELD scores greater than 40 are all grouped together and receive a score of 40)".

Despite the fact that it should be impossible to achieve a MELD score of $>40$, many of the online calculators do indeed generate numbers greater than this ceiling value. This is dependent upon numbers entered for the international normalised ratio (INR), bilirubin and creatinine. We would therefore caution all clinicians when using these or similar calculators to analyse retrospective data. MELD scores can easily and incorrectly be generated with values $>40$.

Calculation of the median score (with interquartile ranges) would not highlight this problem, but sample mean and SD may do. These values may skew the data-for example, the 3-month survival probability with a MELD score of 40 should actually be lower than depicted on the graph, and the mean MELD score in table 1 should be $<18$.

This has potential ramifications for all large multicentre trials and systematic reviews utilising published MELD scores collected in this way.

We would also like to add comment to sodium not meeting the fourth criterion of "stability" in a scoring system for organ allocation. Sodium levels, like creatinine, can easily be manipulated through overzealous diuretic usage. Perhaps the measurement of variables not directly influenced by diuretic use would be of benefit.

\section{Coltart, M Austin, D L Shawcross}

Institute of Liver Studies, King's College Hospital, London UK

Correspondence to: Dr D L Shawcross, Institute of Liver Studies, Cheyne Wing, Kings College Hospital, Denmark Hill, London SE5 9RS, UK; debbie.shawcross@kcl.ac.uk

Competing interests: None.

\section{REFERENCE}

1. Kamath PS, Wiesner RH, Malinchoc M, et al. A model to predict survival in patients with end-stage liver disease. Hepatology 2001;33:464-70.

\section{Toxigenic and non-toxigenic} Clostridium difficile: determinants of intestinal colonisation and role

\section{manifestations}

In a previous paper published in this journal, we reported on the role of the intestinal microbiota in the development of atopic manifestations, as examined in a prospective birth cohort (KOALA). ${ }^{1}$ We showed that infants colonised with Clostridium difficile were at increased risk of developing eczema, wheeze and sensitisation. An association between $C$ difficile and atopic diseases has also been reported by others. ${ }^{2}$

A possible underlying mechanism could be through breaking oral tolerance, as $C$ difficile can cause inflammation in gut tissues, in childhood atopic

leading to increased permeability of the mucosal barrier and thus facilitating the penetration of allergens. ${ }^{4}$ The enteropathogenicity of $C$ difficile is associated with the production of toxins $\mathrm{A}$ and $\mathrm{B}$, encoded by the genes $t c d A$ and $t c d B$. Both toxins disrupt epithelial cell tight junctions and thereby ablate epithelial barrier function. ${ }^{5}$ According to the hypothesised mechanism, it is expected that especially infants colonised with toxin-producing strains are at increased risk of developing atopic diseases.

The aim of this study was to examine which factors influence (non-) toxigenic C difficile colonisation and to examine the role of $C$ difficile toxigenicity on the development of atopic manifestations.

Faecal samples of 957 one-month-old infants, participating in the KOALA study, were available for analysis (for a detailed description of methods see Penders et $a l^{1}$ ). The samples have been subjected to realtime PCRs for the detection of $C$ difficile and its toxins $\mathrm{A}$ and $\mathrm{B}$, according to the assays as described in Penders et $a l^{1}$, Belanger et $a l^{5}$ and van den Berg et $\mathrm{al}^{6}$, respectively.

Information on potential determinants of (non-)toxigenic $C$ difficile colonisation, atopic symptoms and potential confounders was retrieved through repeated questionnaires. Specific immunoglobulin E (IgE) was
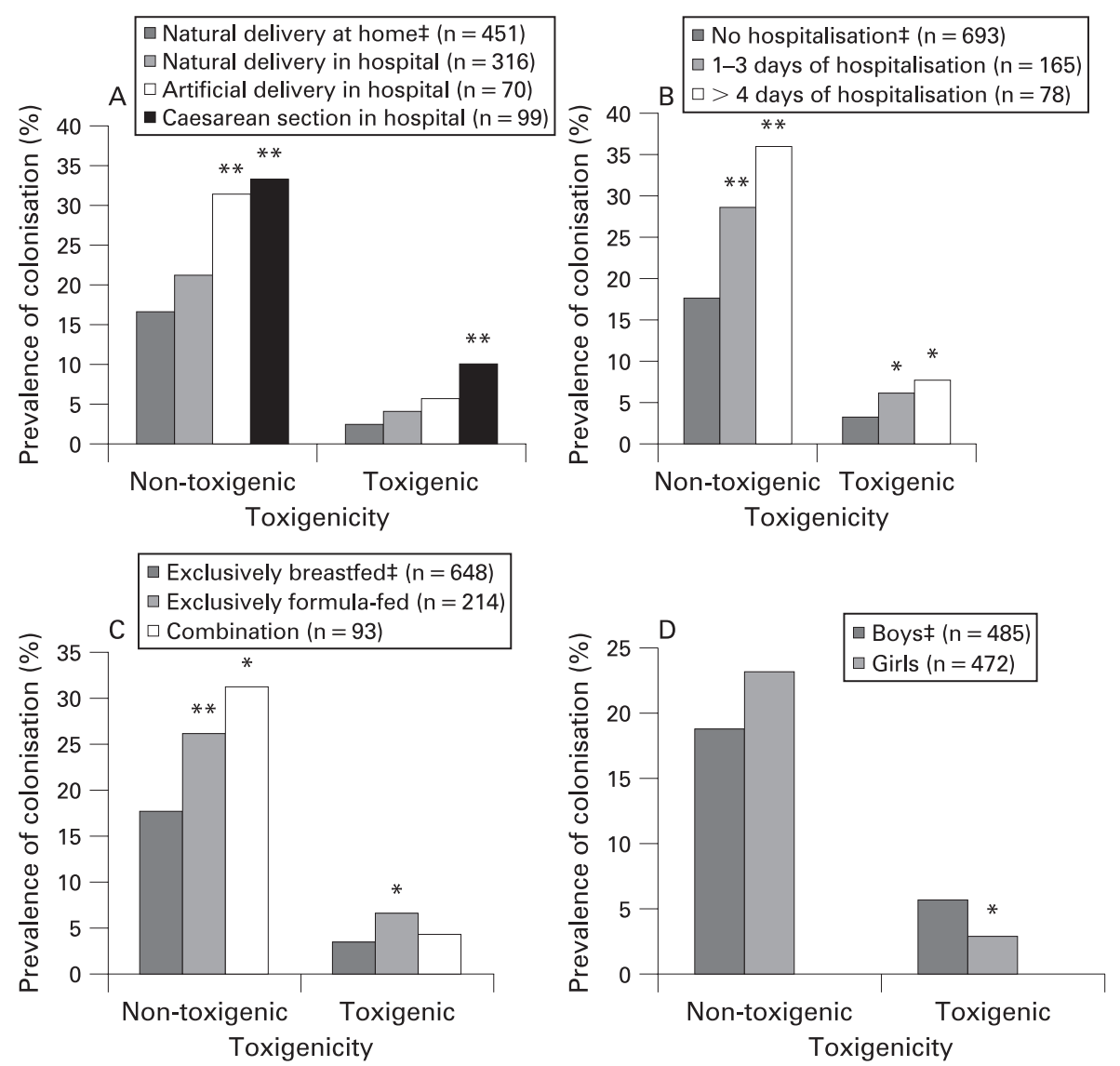

Figure 1 Faecal counts of $C$ difficile in infants colonised with non-toxigenic (median 4.68 $\log 10$ colony-forming units (CFU) $/ \mathrm{g} ; 95 \%$ range $2.73-8.23$ ) and toxigenic (median $7.55 \log 10 \mathrm{CFU} / \mathrm{g}$; range 3.0-8.41) strains. \$Reference category

measured in blood samples collected at the infant's age of 1 and 2 years. A clinical diagnosis of eczema was made at 2 years.

A total of 200 infants $(20.9 \%)$ were colonised with non-toxigenic $\left(\mathrm{A}^{-} \mathrm{B}^{-}\right), 36(3$ $8 \%)$ with toxigenic $\mathrm{A}^{+} \mathrm{B}^{+}$and $4(0.4 \%)$ with toxigenic $\mathrm{A}^{-} \mathrm{B}^{+} \mathrm{C}$ difficile. Hospital delivery (especially caesarean section) and hospital admission following birth were associated with higher colonisation rates of both toxigenic and non-toxigenic $C$ difficile. Exclusively breastfed infants were less often colonised with (non-)toxigenic strains compared with their formula-fed counterparts. Boys were at increased risk of being colonised with toxigenic strains (fig 1). Maternal education, maternal organic and/or vegetarian diet, maternal probiotic and antibiotic use during pregnancy, birth season, number of siblings, fever in the first month of life and the presence of furry pets were not associated with colonisation by either nontoxigenic or toxigenic $C$ difficile.

Colonisation of infants with non-toxigenic, but not with toxigenic, $C$ difficile increased the risk of developing (parentally reported and clinically diagnosed) eczema and sensitisation to food allergens (tables 1 and 2). This implies that toxins $A$ and $B$ are not responsible for the increased risk of eczema and sensitisation among carriers of $C$ difficile. The different 
Table 1 Association between colonisation with (non-)toxigenic $C$ difficile at 1 month of age and atopic manifestation at 2 years of age $(n=957)$

\begin{tabular}{|c|c|c|c|c|c|c|}
\hline & \multicolumn{2}{|c|}{ Parentally reported eczema $\uparrow$} & \multicolumn{2}{|c|}{ Clinically diagnosed eczema (UK-WP): } & \multicolumn{2}{|l|}{ Recurrent wheeze $\dagger$} \\
\hline & Prevalence (n/N§) & ORadj $(95 \% \mathrm{Cl}) \uparrow$ & Prevalence $(\mathrm{n} / \mathrm{N} \S)$ & ORadj (95\% CI) & Prevalence $(\mathrm{n} / \mathrm{N} \S)$ & ORadj (95\% CI) \\
\hline \multicolumn{7}{|l|}{ C difficile } \\
\hline Absent & $30.3 \%(213 / 702)$ & 1.0 & $14.1 \%(64 / 454)$ & 1.0 & $9.4 \%(63 / 671)$ & 1.0 \\
\hline Toxigenic & $31.6 \%(12 / 38)$ & $1.13(0.55$ to 2.31$)$ & $17.1 \%(6 / 35)$ & $1.40(0.55$ to 3.58$)$ & $21.6(8 / 37)$ & $3.92^{* *}(1.62$ to 9.44$)$ \\
\hline
\end{tabular}

${ }^{*} \mathrm{p}<0.05 ;{ }^{* *} \mathrm{p}<0.005$

$\dagger$ Based on parental reports in 7, 12 and/or 24 months questionnaires.

As determined by trained nurses during home-visits (according to UK Working Party criteria (UK-WP)

§Numbers in the table do not always add up to 957 due to missing outcome data.

-Adjusted ORs (ORadj) and 95\% Cl from logistic regression analysis: adjusted for subcohort, parental history of atopy, siblings history of atopy, age at collection of faecal sample and infant's gender.

Table 2 Association between colonisation with (non-)toxigenic $C$ difficile at 1 month of age and atopic sensitisation at $1(\mathrm{n}=613)$ and $2(\mathrm{n}=583$ ) years of age

\begin{tabular}{|c|c|c|c|c|c|c|}
\hline & \multicolumn{2}{|c|}{ Sensitisation to food allergens age 1 year $\dagger$} & \multicolumn{2}{|c|}{ Sensitisation to food allergens age 2 years $\uparrow$} & \multicolumn{2}{|c|}{ Sensitisation to aeroallergens age 2 years } \\
\hline & Prevalence (n/N§) & ORadj (95\% CI) & Prevalence (n/N) & ORadj (95\%Cl) & Prevalence (n/N§) & ORadj (95\%Cl) \\
\hline \multicolumn{7}{|l|}{ C difficile } \\
\hline Absent & $13.3 \%(61 / 460)$ & 1.0 & $19.5 \%(86 / 440)$ & 1.0 & $13.2 \%(49 / 370)$ & 1.0 \\
\hline Non-toxigenic & $22.3 \%(27 / 121)$ & $1.91^{*}(1.14$ to 3.18$)$ & $30.3 \%(33 / 109)$ & $1.85^{*}(1.14$ to 3.00$)$ & $15.8 \%(15 / 95)$ & $1.16(0.61$ to 2.19$)$ \\
\hline Toxigenic & $15.6 \%(5 / 32)$ & $1.11(0.4$ to 3.05$)$ & $20.6(7 / 34)$ & 1.08 (0.45 to 2.62$)$ & $14.8 \%(4 / 27)$ & $1.08(0.35$ to 3.31$)$ \\
\hline
\end{tabular}

${ }^{*} \mathrm{p}<0.05 ;{ }^{* *} \mathrm{p}<0.005$.

† Specific immunoglobulin $\mathrm{E}$ antibodies to at least one food allergen (cow's milk, hen's egg, peanut), cut-off values $0.35 \mathrm{IU} / \mathrm{ml}$ (age 1 year) and $0.3 \mathrm{IU} / \mathrm{ml}$ (age 2 years).

Specific immunoglobulin E antibodies to at least one aeroallergen (birch, grass pollen, cat, dog, house dust mite), cut-off value $0.3 \mathrm{IU} / \mathrm{ml}$.

$\S$ Numbers in the table do not add up to 583 due to missing outcome data.

-From logistic regression analysis: adjusted for subcohort, parental history of atopy, siblings history of atopy, age at collection faecal sample and infant's gender

associations of non-toxigenic and toxigenic $C$ difficile with these atopic outcomes suggest that other bacterial components or properties, differing between toxin-positive and toxinnegative strains, may play a role.

In contrast to eczema and sensitisation to food allergens, recurrent wheeze was positively associated with toxin-positive $C$ difficile (table 1). This could indicate different biological mechanisms underlying the aetiology of wheeze compared with eczema and sensitisation.

In conclusion, the present study showed that although both non-toxigenic and toxigenic $C$ difficile strains share the same environmental origin, they are differently associated with atopic manifestations. In contradiction of our hypothesis, the association between $C$ difficile and eczema and sensitisation cannot be explained by disruption of the epithelial barrier function by toxins $\mathrm{A}$ and $\mathrm{B}$. The different associations between non-toxigenic and toxigenic C. difficile with atopic manifestations, however, demonstrate the importance of studying the effect of gut bacteria in health and disease beyond the genus and species level. Further investigations are necessary to understand better the role of non-toxigenic $C$ difficile strains in disease development.

\section{J Penders, ${ }^{1,2}$ E E Stobberingh, ${ }^{2}$ P A van den Brandt, ${ }^{3}$} R van Ree, ${ }^{4}$ C Thijs ${ }^{1,3}$

${ }^{1}$ Department of Epidemiology, Nutrition and Toxicology Research Institute Maastricht (NUTRIM), Maastricht University, Maastricht, The Netherlands; ${ }^{2}$ Department of Medical Microbiology, University Hospital of Maastricht, Maastricht, The Netherlands; ${ }^{3}$ Department of Epidemiology, Care and Public Health Research Institute (Caphri),

Maastricht University, Maastricht, The Netherlands;
${ }^{4}$ Department of Experimental Immunology, Academic Medical Center, Amsterdam, The Netherlands

Correspondence to: Dr J Penders, Department of Epidemiology, Nutrition and Toxicology Research Institute Maastricht (NUTRIM), Maastricht University, P0 Box 616, 6200 MD Maastricht, The Netherlands; j.penders@ epid.unimaas.nl

Funding: This study was partly supported by grants from the Dutch Asthma Foundation (grant 3.2.03.48), the Faculty of Health Sciences of the Maastricht University (Talent for the future scholarship) and Royal Friesland Foods (the Netherlands).

Competing interests: None.

Ethics approval: The KOALA study was approved by the Ethical Committee of the University Hospital of Maastricht

Patient consent: All parents signed informed consent for the study.

\section{Gut 2008;57:1025-1026. doi:10.1136/gut.2007.143214}

\section{REFERENCES}

1. Penders J, Thijs C, van den Brandt PA, et al., Gut microbiota composition and development of atopic manifestations in infancy: the KOALA Birth Cohort Study. Gut 2007; 56:661-7.

2. Woodcock A, Moradi M, Smillie Fl, et al. Clostridium difficile, atopy and wheeze during the firs year of life. Pediatr Allergy Immunol 2002;13:357-60.

3. Bottcher MF, Nordin EK, Sandin A, et al. Microfloraassociated characteristics in faeces from allergic and nonallergic infants. Clin Exp Allergy 2000;30:1590-6.

4. Sepp E, Julge $\mathrm{K}$, Mikelsaar M, et al. Intestinal microbiota and immunoglobulin $\mathrm{E}$ responses in 5-yearold Estonian children. Clin Exp Allergy 2005;35:141-6.

5. Belanger SD, Boissinot M, Clairoux N, et al Rapid detection of Clostridium difficile in feces by realtime PCR. J Clin Microbiol 2003;41:730-4.

6. van den Berg RJ, Kuijper EJ, van Coppenraet LE et al. Rapid diagnosis of toxinogenic Clostridium difficile in faecal samples with internally controlled real-time PCR. Clin Microbiol Infect 2006:12:184-6.
Upper gastrointestinal symptoms and asthma: a manifestation of allergy?

We welcomed the systematic review by Havemann et al (Gut 2007;56:1654) further highlighting the significance of the association between gastro-oesophageal reflux disease (GORD) and asthma. The importance of this association is underlined by the magnitude of published studies concerning this subject (731 studies evaluated in Havemann's review). The reviewers conceded that the direction of causality and the underlying mechanism responsible for this association remain undetermined. Mechanisms postulated include hyperexpansion of the asthmatic chest leading to failure of the gastro-oesophageal junction (GOJ) with attendant reflux symptoms, or shared stimulation of vagus nerve-mediated reflex arcs resulting in both bronchial smooth muscle constriction (causing asthma) and GOJ relaxation (causing GORD). Causality has also been speculated to occur in the reverse direction, with aspiration of gastric fluid into the bronchial tree of patients with GORD leading to symptomatic bronchial irritability and asthma.

An alternative explanation also merits consideration. Asthma is characterised by increased numbers of eosinophils in the bronchial mucosa, airways lumen and circulating blood, in numbers that correlate with asthma severity. ${ }^{1}$ It appears that in patients with allergic diseases such as asthma and allergic rhinitis, the migration 